\title{
PENGARUH NILAI YANG DITERIMA PELANGGAN DAN KUALITAS PELAYANAN TERHADAP LOYALITAS PELANGGAN : KEPUASAN PELANGGAN SEBAGAI MEDIATOR DAN GENDER SEBAGAI MODERATOR
}

(Studi Pada PT.KAI Kota Malang)

\author{
Evan Chandra Kusuma \\ Fakultas Ekonomi dan Bisnis Universitas Brawijaya \\ E-mail : evan chk@yahoo.com
}

\begin{abstract}
The objective of this study is to examine and analyze the direct impact of perceived value and service quality on customer satisfaction and customer loyalty. This study also examine and analyze the indirect impact of perceived value and service quality on customer loyalty with customer satisfaction as mediation variable. In addition, it also examine the indirect impact of perceived value, service quality, and customer satisfaction on customer loyalty with gender as moderation variable.The study surveyed a sample of 120 respondents in Kota Baru Train Station in Malang City. Purposive sampling was chosen as a method to determine the samples. The study used Partial Least Square (PLS) - Structural Equation Model (SEM) as analytical tools to test the hypothesis. The results showed that perceived value and service quality has impact on customer satisfaction, perceived value and customer satisfaction has an impact on customer loyalty, service quality has no significant impact on customer loyalty, customer satisfaction mediates the impact of perceived value on customer loyalty, customer satisfaction mediates the impact of service quality on customer loyalty, gender has not moderatory impact of perceived value, service quality, and customer satisfaction on customer loyalty.
\end{abstract}

Keywords: Customer Loyalty, Customer Satisfaction, Gender, Perceived Value, Service Quality

Abstrak : Tujuan dari penelitian ini adalah untuk mengetahui pengaruh nilai yang diterima pelanggan dan kualitas pelayanan secara langsung pada kepuasan dan loyalitas karyawan pada PT KAI Kota Malang. Selain itu, hal itu dilakukan untuk mengetahui pengaruh tidak langsung dari nilai yang diterima pelanggan dan kualitas layanan loyalitas pelanggan melalui kepuasan pelanggan. Kemudian untuk mengetahui peran gender sebagai moderator pada loyalitas pelanggan. Dalam penelitian ini, data dikumpulkan menggunakan kuesioner dengan Skala Likert, dan kemudian didistribusikan ke 120 pelanggan PT KAI Kota Malang. Partial Least Square (PLS) digunakan untuk menganalisis data. Temuan penelitian ini menunjukkan bahwa nilai yang diterima pelanggan memiliki pengaruh langsung positif dan signifikan terhadap kepuasan dan loyalitas karyawan. Sedangkan kualitas pelayanan tidah secara langsung berpengaruh signifikan terhadap loyalitas pelanggan. Selanjutnya, dalam penelitian ini ditemukan bahwa nilai yang diterima pelanggan dan kualitas layanan memiliki efek positif dan signifikan terhadap loyalitas karyawan melalui kepuasan pelanggan. Kemudian gender tidak memoderasi hubungan antara nilai yang diterima pelanggan, kualitas pelayanan, kepuasan pelanggan dengan loyalitas pelanggan.

Kata Kunci: Gender, Kepuasan Pelanggan, Kualitas Pelayanan, Loyalitas Pelanggan, Nilai Yang Diterima Pelanggan 


\section{Pendahuluan}

Indonesia dengan 71.190 .000 pengguna telah menjadi pengguna Internet peringkat keempat di Asia atau 11 di dunia (Anonymous, 2015). Menurut data dari survey TechinAsia masyarakat Indonesia telah melakukan transaksi jual-beli online atau daring mencapai Rp34,3 triliun pada tahun 2014 dan diprediksikan pada tahun 2016 pertumbuhan transaksi online akan meningkat dua kali lipat menjadi sebesar Rp64,5 triliun. (Anonymous, 2015). Data tersebut merupakan sebuah peluang yang dapat digunakan oleh pengusaha-pengusaha di Indonesia untuk menciptakan bisnis yang berbasiskan Internet misalnya electronic commerce (e-commerce). E-commerce saat ini dapat dibangun dengan mudah karena akses Internet lebih murah dari sebelumnya dan terdapat banyak bank yang menyediakan fitur Internet Banking (e-banking) yang dapat membantu mendukung proses pembayaran dalam e-commerce sehingga dapat berkembang dengan cepat. Tidak setiap situs e-commerce yang dibangun dapat menjual produk atau jasa yang ditawarkan dengan mudah. Fakta menunjukkan bahwa hanya sebesar $6 \%$ dari pengguna Internet yang melakukan transaksi di situs-situs e-commerce (Purwanto, 2011).

PT Kereta Api Indonesia (KAI) memberikan kemudahan masyarakat untuk bisa membeli tiket secara online sehingga calon penumpang tidak perlu datang ke stasiun dan antre berdesak-desakan. PT KAI telah menyosialisasikan penjualan tiket secara online sejak 7 tahun lalu. Kini, sedang gencargencarnya penjualan melalui minimarket, kantor pos, reservasi, internet, dan sebagainya (Rochmanuddin,2013). Sejak bulan April 2014 tidak ada perbedaan harga membeli tiket secara online maupun secara langsung di loket stasiun (Hidayat, 2014). Fenomena ini berarti PT. KAI harus mengubah cara konsumen dalam pembelian tiket kereta dari pembelian melalui loket di stasiun menjadi pembelian secara online untuk mengurangi antrean, serta meminimalkan praktik calo tiket.

Penelitan yang dilakukan adalah untuk mengetahui faktor-faktor yang mempengaruhi loyalitas pelanggan dalam membeli tiket kereta api melalui e-commerce. Sehingga dapat digunakan bagi perusahaan maupun pengusaha yang ingin membangun sebuah situs ecommerce yang sesuai dengan keinginan pasar di Indonesia dan tidak membangun website ecommerce yang gagal. Salah satu faktor tersebut ialah nilai yang diterima oleh pelanggan. Menurut Zeithaml (1988) dalam jurnal (Pearson, Tadisina, \& Griffin, 2012), mengaitkan value dengan empat tema: value itu harga yang rendah, value adalah apapun yang diinginkan seseorang ada dalam suatu produk, value adalah kualitas yang diterima oleh setiap individu yang dibayarkan pada produk tersebut, dan value adalah apa yang diterima sesuai dengan apa yang dibayarkan.

Persepsi (atau konsumen) nilai interaktif antara subjek (pelanggan) dan obyek (produk). Berkaitan dengan situs, value yang dirasakan tidak berhubungan banyak untuk biaya secara moneter yang terkait dengan penggunaannya, tetapi, seperti yang dinyatakan oleh Kim dan Niehm (2009), merupakan kemungkinan untuk melakukan kunjungan kembali terhadap situs tersebut. (Pearson, Tadisina, \& Griffin, 2012). Terdapat beberapa perbedaan hasil penelitian mengenai hubungan antara nilai terhadap loyalitas konsumen. Dalam penelitian tersebut menggunakan variabel pemediasi untuk melihat hubungan nilai yang diterima dengan loyalitas pelanggan. Penelitian dari Lee (2010) menunjukkan nilai yang diterima pelanggan dimediasi penuh oleh kepuasan konsumen untuk berpengaruh terhadap loyalitas.

Chen dan Tsai (2008) melakukan penelitian tentang keterlibatan moderator dalam menguji hubungan antara nilai yang diterima, kepuasan dan loyalitas pelanggan. Hubungan antara nilai yang diterima pelanggan tidak dimediasi secara penuh oleh kepuasan pelanggan untuk berpengaruh terhadap loyalitas pelanggan.

E-Service quality dapat didefinisikan
sebagai tanggapan pelanggan secara keseluruhan dan penilaian mengenai keunggulan dan kualitas pengiriman e-service di pasar virtual (Santos, 2003). Penilaian baik atau buruknya kualitas jasa sangat berkaitan dengan rasa puas ataupun tidak puas pengguna jasa tersebut. Antara kualitas jasa dan kepuasan sangat berkaitan erat meskipun keduanya mempunyai pengertian dan konsep yang berbeda. Ketika kepuasan membandingkan persepsi konsumen pada apa yang kosumen harapkan secara normal, kualitas pelayanan membandingkan persepsi pada apa yang konsumen harapkan dari perusahaan yang mengantarkan pelayanan berkualitas tinggi.

Ada beberapa penelitian akademis yang

fokus pada pengukuran kualitas layanan. 
SERVQUAL tradisional atau" gap" model analisis yang dikembangkan oleh Parasuraman, Zeithaml dan Berry pada awal tahun 1980, yang didasarkan pada pandangan bahwa pelanggan menilai kualitas pelayanan dengan membandingkan harapan layanan yang diberikan dengan persepsi layanan aktual yang diterima dari penyedia layanan tertentu. Hal tersebut dibuktikan dari beberapa penelitian terdahulu yang mendukung, namun ada beberapa penelitian yang memiliki hasil bertentangan dengan penelitian yang mendukung tersebut, sehingga menjadi research gap pada penelitian kali ini. Kualitas pelayanan memiliki dampak yang langsung terhadap kepuasan pelanggan yang akan meningkatkan keuntungan perusahaan (Cristobal, et al., 2007). Penelitian Kuo, et al. (2009) dan Lee (2010) menunjukkan kualitas pelayanan memberikan pengaruh langsung signifikan terhadap kepuasan pelanggan. Sementara itu Kim, et al. (2009) dalam penelitiannya menunjukkan faktor kualitas, yaitu daya tanggap tidak memberikan pengaruh langsung dan tidak signifikan terhadap kepuasan pelanggan. Sedangkan faktor kualitas pelayanan yang lain seperti pemenuhan, desain, dan keamanan website memberikan pengaruh langsung dan signifikan terhadap kepuasan pelanggan. Penelitian Lee, et al. (2009) menujukkan secara keseluruhan faktor kualitas layanan dibentuk oleh efisiensi dan pemenuhan layanan, dengan pemenuhan layanan memainkan peran yang sangat penting.

Hubungan antara penerapan $e$ commerce dengan kepuasan konsumen dinyatakan oleh Ahmadi (2011) yang menyatakan bahwa ditinjau dari perspektif pelayanan, e-commerce merupakan salah satu alat yang memenuhi keinginan perusahaan dalam meningkatkan mutu barang dan kecepatan pelayanan sehingga dapat meningkatkan kepuasan konsumen. Penelitian dari Lee (2010) menunjukkan kualitas pelayanan dimediasi penuh oleh kepuasan konsumen untuk berpengaruh terhadap loyalitas. Hasil tersebut dikuatkan juga oleh penelitian yang dilakukan oleh Auka (2012) yang menyatakan kualitas pelayanan dimediasi penuh oleh kepuasan konsumen untuk berpengaruh terhadap loyalitas.

Elkhani, et al. (2014) dalam penelitiannya mengemukakan kualitas informasi dan kualitas pelayanan dimediasi secara sebagian oleh kepuasan konsumen untuk berpengaruh terhadap loyalitas. Sedangkan kualitas sistem dimediasi secara penuh oleh kepuasan konsumen untuk berpengaruh terhadap loyalitas.

Pembelian melalui tiket KAI secara online dapat melakukan pemesanan secara virtual di manapun, 24 jam dalam satu hari, 7 hari dalam 1 minggu tanpa terbatasi oleh jam kerja, maupun jarak. Hasil riset, perempuan memang menempati urutan pertama dengan presentase $57 \%$, namun pria yang melakukan transaksi melalui e-commerce juga tidak berbeda jauh yakni sebanyak 47\% (Anjani, 2015). Hal ini dikuatkan oleh survei yang dilakukan oleh forum online Female Daily Network yang menunjukkan sekitar 65 persen keputusan belanja melalui e-commerce ditentukan oleh wanita (Noviandari, 2014). Menurut Kotler (2009) jenis kelamin merupakan salah satu faktor yang mempengaruhi perilaku konsumen. Selain itu Heilburn (2002) menyatakan bahwa maskulinitas dan feminitas telah dikonsepkan sebagai dua hal yang berlawanan. Secara konsekuen, masyarakat memberikan peran yang unik bagi laki-laki maupun perempuan. Sejak dahulu telah dapat diterima bahwa kualitas psikologis laki-laki adalah berbeda dengan perempuan. Hal ini menyebabkan adanya perbedaan sikap atau norma pada gender. Sehingga tidak menutup keinginan bahwa tingkat loyalitas antara lakilaki dan perempuan berbeda.

Penelitian Hamidizadeh, et al (2011) yang menunjukkan menunjukkan gender tidak memoderasi hubungan antara kepuasan pelanggan dan loyalitas pelanggan. Diperkuat oleh penelitian Stan (2015); dan Frank, et al (2013) yang menujukkan gender juga tidak memoderasi hubungan antara kepuasan pelanggan dan loyalitas pelanggan. Berdasarkan latar belakang penelitian ini, serta informasi riset terdahulu maka peneliti tertarik untuk mengembangkan penelitian

\section{Tinjauan Pustaka}

Kotler dan Keller (2013) mendefinisikan jasa sebagai tindakan yang dapat ditawarkan oleh suatu pihak kepada pihak lain, dimana dasarnya tidak mempunyai wujud dan tidak mengakibatkan kepemilikan apapun. Produksi jasa dikaitkan atau tidak dikaitkan pada suatu produk fisik. Perkembangannya sekarang ini internet digunakan untuk mendukung bisnis, yang dikenal dengan electronic commerce (e-commerce), dalam perkembangannya E-commerce mencapai lini 
perbankan atau yang sering disebut Internet Banking. Yang dimaksud dengan Electronic Commerce berhubungan dengan cakupan aktifitas luas bisnis online dari produk dan layanan. E-commerce juga berkaitan dengan segala bentuk transaksi bisnis dimana beberapa pihak berinteraksi secara elektronik, bukannya secara pertukaran fisik atau kontak fisik langsung (Sussanah, 2005).

Zeithaml (2000) mendefinisikan perceived value sebagai penilaian keseluruhan dari pelanggan mengenai kegunaan atau manfaat dari produk maupun jasa berdasarkan persepsi yang berkaitan dengan apa yang diterima dan apa yang diberikan. Sedangkan Kotler dan Keller (2013) mendefinisikan nilai pelanggan adalah perbedaan antara nilai pelanggan total dengan biaya pelanggan total. Nilai yang diterima pelanggan (customer perceived value) adalah selisih antara evaluasi calon pelanggan atas semua manfaat serta biaya tawaran tertentu dan alternatif-alternatif lain yang dipikirkan.

Menurut Kotler dan Keller (2013) definisi pelayanan adalah setiap tindakan atau kegiatan yang dapat ditawarkan oleh suatu pihak kepada pihak lain, yang pada dasarnya tidak berwujud dan tidak mengakibatkan kepemilikan apapun. Produksinya dapat dikaitkan atau tidak dikaitkan pada satu produk fisik. Pelayanan merupakan perilaku produsen dalam rangka memenuhi kebutuhan dan keinginan konsumen demi tercapainya kepuasan pada konsumen itu sendiri. Kotler dan Keller (2013) juga mengatakan bahwa perilaku tersebut dapat terjadi pada saat, sebelum dan sesudah terjadinya transaksi. Pada umumnya pelayanan yang bertaraf tinggi akan menghasilkan kepuasan yang tinggi serta pembelian ulang yang lebih sering.

Kepuasan adalah perasaan senang atau kecewa seseorang yang timbul setelah membandingkan kinerja atau hasil suatu produk yang dipersepsikan terhadap ekspektasi mereka. Jika kinerja gagal memenuhi ekspektasi, maka pelanggan tidak akan puas. Jika kinerja sesuai dengan ekspektasi, maka pelangga akan puas. Dan jika kinerja melebihi ekspektasi, maka pelanggan akan sangat puas (Kotler dan Keller, 2013). Sehingga hal ini dapat membawa dampak negatif bagi perusahaan, yaitu dapat menurunkan jumlah pelanggan dan menyebabkan perusahaan tidak tertarik lagi untuk menggunakan jasa perusahaan.

Menurut Mowen dan Minor (2002) definisi loyalitas adalah kondisi dimana konsumen mempunyai sikap positif terhadap suatu merek, mempunyai komitmen terhadap merek tersebut, dan bermaksud untuk meneruskan pembelian di masa mendatang. Sedangkan menurut Tjiptono (2000) loyalitas konsumen adalah komitmen pelanggan terhadap suatu merek, toko atau pemasok berdasarkan sifat yang sangat positif dalam pembelian jangka panjang. Artinya, bahwa kesetiaan terhadap merek diperoleh karena adanya kombinasi dari kepuasan dan keluhan. Sehingga kepuasan pelanggan tersebut hadir dari seberapa besar kinerja perusahaan untuk menimbulkan kepuasaan tersebut dengan meminimalkan keluhan sehingga diperoleh pembelian jangka panjang yang dilakukan oleh konsumen.

Menurut Tierney (2009) dijelaskan bahwa gender adalah konsep kultural yang berupaya membuat pembedaan dalam hal peran, perilaku, mentalitas, dan karakteristik emosional laki-laki dan perempuan yang berkembang dalam masyarakat

\section{Kerangka Konsep Penelitian}

Penyusunan kerangka konseptual dalam penelitian ini dilandasi oleh fenomena maraknya e-commerce dalam dunia bisnis. Hasil penelitian terdahulu menunjukkan kepuasan pelanggan dipengaruhi oleh nilai yang diterima pelanggan (Kuo, et al., 2009; Auka, 2012; Lee, 2010; dan Chen dan Tsai, 2008) dan kualitas pelayanan (Elkhani, et al., 2014; Kuo, et al., 2009; Kim, et al., 2009; Lee, et al., 2009; Lee, 2010; dan Cristobal, et al., 2007).

Hasil penelitian terdahulu juga menunjukkan beberapa faktor yang mempengaruhi loyalitas pelanggan. Penelitian Elkhani, et al. (2014); Auka (2012); Cristobal, et al. (2007); serta Chen dan Tsai (2008) menunjukkan adanya pengaruh kepuasan pelanggan terhadap loyalitas pelanggan. Ishaq (2012); Lee (2010); serta Chen dan Tsai (2008) dalam penelitiannya menunjukkan nilai yang diterima pelanggan berpengaruh terhadap loyalitas pelanggan. Penelitian yang dilakukan oleh Auka (2012); Ishaq (2012); Lee (2010); dan Cristobal, et al. (2007) menunjukkan kualitas pelayanan berpengaruh terhadap loyalitas pelanggan.

\section{Hipotesis Penelitian}

Nilai yang diterima oleh pelanggan merupakan salah satu hal yang penting dalam menciptakan kepuasan pelanggan. Penelitian yang dilakukan oleh Kuo, et al. (2009) 
menunjukkan bahwa nilai yang diterima oleh pelanggan memberikan pengaruh signifikan terhadap kepuasan pelanggan.

H1: $\quad$ Nilai yang diterima pelanggan memiliki pengaruh signifikan terhadap kepuasan pelanggan.

Nilai yang diterima pelanggan merupakan imbalan yang diterima oleh pelanggan atas kualitas dan pengorbanan yang membuat pelanggan tetap menggunakan jasa layanan yang ditawarkan (Lee, 2010). Penelitian yang dilakukan oleh Ishaq (2012); Auka (2012); dan Chen dan Tsai (2008). Menunjukkan nilai yang diterima pelanggan berpengaruh secara signifikan terhadap loyalitas pelanggan. Oleh karena itu dapat dikemukakan hipotesis keempat sebagai berikut:

H2: Nilai yang diterima pelanggan memiliki pengaruh signifikan terhadap loyalitas pelanggan.

Kim, et al. (2009) dalam penelitiannya menunjukkan faktor kualitas, yaitu daya tanggap tidak memberikan pengaruh langsung dan tidak signifikan terhadap kepuasan pelanggan. Sedangkan faktor kualitas pelayanan yang lain seperti pemenuhan, desain, dan keamanan website memberikan pengaruh langsung dan signifikan terhadap kepuasan pelanggan. Oleh karena itu dapat dikemukakan hipotesis kedua sebagai berikut:

H3: Kualitas pelayanan memiliki pengaruh signifikan terhadap kepuasan pelanggan.

Penelitian Cristobal, et al. (2007) menunjukkan kualitas pelayanan tidak berpengaruh secara signifikan terhadap terhadap loyalitas pelanggan dalam kelompok pembeli, hal ini karena masih adanya kekhawatiran para pembeli bila akan keamanan data yang diberikan akan disalahgunakan oleh penyedia jasa. Oleh karena itu dapat dikemukakan hipotesis kelima sebagai berikut:

H4: Kualitas pelayanan memiliki pengaruh signifikan terhadap loyalitas pelanggan.

Elkhani, et al. (2014) dalam penelitiannya menunjukkan kepuasan pelanggan berpengaruh secara langsung dan signifikan terhadap loyalitas pelanggan. Dalam penelitiannya didefinisikan bahwa loyalitas pelanggan secara eksplisit sebagai keputusan untuk membeli layanan kembali dan merekomendasikan layanan terhadap orang lain. Oleh karena itu dapat dikemukakan hipotesis ketiga sebagai berikut:

H5: Kepuasan pelanggan memiliki pengaruh signifikan terhadap loyalitas pelanggan.
Penelitian dari Lee (2010) menunjukkan nilai yang diterima pelanggan dimediasi penuh oleh kepuasan konsumen untuk berpengaruh terhadap loyalitas. Hasil tersebut dikuatkan juga oleh penelitian yang dilakukan oleh Auka (2012) yang menyatakan nilai yang diterima pelanggan dimediasi penuh oleh kepuasan konsumen untuk berpengaruh terhadap loyalitas. H6: Nilai yang diterima pelanggan memiiki pengaruh terhadap loyalitas pelanggan dengan dimediasi oleh kepuasan pelanggan

Penelitian dari Lee (2010) menunjukkan kualitas pelayanan dimediasi penuh oleh kepuasan konsumen untuk berpengaruh terhadap loyalitas. Hasil tersebut dikuatkan juga oleh penelitian yang dilakukan oleh Auka (2012) yang menyatakan kualitas pelayanan dimediasi penuh oleh kepuasan konsumen untuk berpengaruh terhadap loyalitas.

H7: Kualitas pelayanan memiliki pengaruh terhadap loyalitas pelanggan dengan dimediasi oleh kepuasan pelanggan

Penelitian Stan (2015) yang menunjukkan gender tidak memoderasi hubungan antara nilai yang diterima pelanggan dan loyalitas pelanggan Oleh karena itu dapat dikemukakan hipotesis kedelapan sebagai berikut :

H8: Nilai yang diterima pelanggan berpengaruh signifikan terhadap loyalitas pelanggan dengan dimoderasi oleh gender

Penelitian Hamidizadeh, et al (2011) menjukkan bahwa gender tidak memoderatori hubungan antara kualitas pelayanan dan loyalitas. Oleh karena itu dapat dikemukakan hipotesis kesembilan sebagai berikut :

H9: Kualitas pelayanan berpengaruh signifikan terhadap loyalitas pelanggan dengan dimoderasi oleh gender

Penelitian Stan (2015); dan Frank, et al (2013) yang menujukkan gender juga tidak memoderasi hubungan antara kepuasan pelanggan dan loyalitas pelanggan. Oleh karena itu dapat dikemukakan hipotesis kesepuluh sebagai berikut:

H10: Kepuasan pelanggan berpengaruh signifikan terhadap loyalitas pelanggan dengan dimoderasi oleh gender

\section{Metode Penelitian}

Jenis penelitian yang digunakan adalah explanatory research. Singarimbun dan Effendi (2008) menjelaskan bahwa penelitian explanatory riset apabila data yang sama peneliti menjelaskan hubungan kausal antara variabel- 
variabel melalui pengujian hipotesis maka penelitian dinamakan penelitian pengujian hipotesis atau penelitian penjelasan.

Teknik analisis yang digunakan dalam penelitian ini adalah Structural Equation Modelling (SEM) dengan menggunakan program Smart PLS. Model persamaan struktural (SEM) adalah sekumpulan teknikteknik statistikal yang memungkinkan pengujian sebuah rangkaian hubungan yang relatif "rumit" secara simultan (Hair et al. 1998). Keunggulan aplikasi SEM dalam penelitian manajemen adalah karena kemampuannya untuk mengonfirmasi dimensi-dimensi dari sebuah konsep atau faktor yang sangat lazim digunakan dalam manajemen serta kemampuannya untuk mengukur pengaruh hubungan-hubungan yang secara teoritis ada.

\section{Hasil dan Pembahasan} Model Struktural (Inner Model)

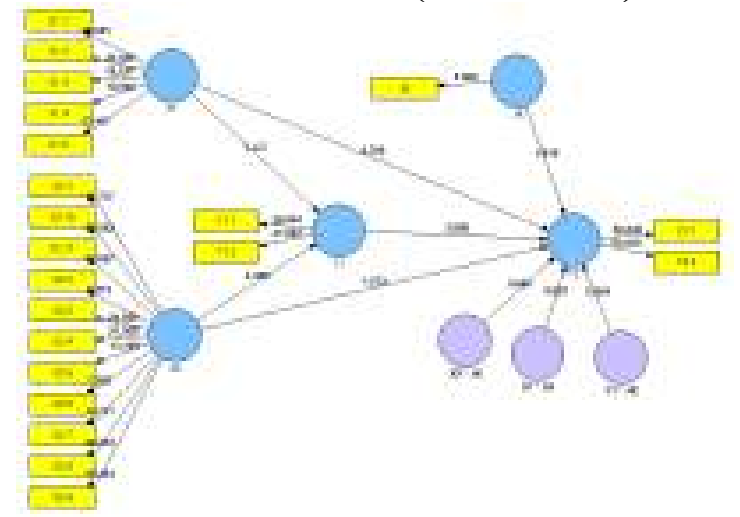

Path Coefficient (Mean, STDEV, T-Values)

\begin{tabular}{rcccc}
\hline Hubungan & $\begin{array}{c}\text { Original } \\
\text { Sample } \\
(\mathrm{O})\end{array}$ & $\begin{array}{c}\text { Standard } \\
\text { Deviation } \\
(\text { STDEV })\end{array}$ & $\begin{array}{c}\text { T Statistics } \\
(|\mathrm{O} / \mathrm{STERR}|)\end{array}$ & Keterangan \\
\hline $\mathrm{X} 1$ - > Y1 & 0.4306 & 0.0794 & 5.4226 & Signifikan \\
\hline $\mathrm{X} 2$-> Y1 & 0.3547 & 0.0809 & 4.385 & Signifikan \\
\hline $\mathrm{X} 1$-> Y2 & 0.2893 & 0.1069 & 2.7062 & Signifikan \\
\hline $\mathrm{X} 2$ - > Y2 & 0.2692 & 0.2605 & 1.0333 & Tidak Signifikan \\
\hline $\mathrm{JK}$-> Y2 & 1.0368 & 1.0186 & 1.0179 & Tidak Signifikan \\
\hline $\mathrm{X} 1 * \mathrm{JK}$-> Y2 & 0.0021 & 0.0942 & 0.0225 & Tidak Signifikan \\
\hline $\mathrm{X} 2 * \mathrm{JK}$-> Y2 & -0.7675 & 1.147 & 0.6691 & Tidak Signifikan \\
\hline $\mathrm{Y} 1 * \mathrm{JK}$-> Y2 & 0.0687 & 0.1218 & 0.5641 & Tidak Signifikan \\
\hline $\mathrm{Y} 1$-> Y2 & 0.2462 & 0.0853 & 2.8878 & Signifikan \\
\hline
\end{tabular}

\begin{tabular}{|c|c|c|c|c|c|c|c|}
\hline \multicolumn{8}{|c|}{ Pengaruh tidak Langsung } \\
\hline \multirow{2}{*}{$\begin{array}{c}\text { Varaibel } \\
\text { X1, Y1, } \\
\text { Y2 }\end{array}$} & \multicolumn{2}{|c|}{$\begin{array}{l}\text { Koefisien } \\
\text { Langsung }\end{array}$} & \multicolumn{2}{|c|}{ standar error } & \multirow{2}{*}{$\begin{array}{c}\begin{array}{c}\text { Koefi } \\
\text { sien } \\
\text { TL }\end{array} \\
0.106\end{array}$} & \multirow[t]{2}{*}{ se Gab } & \multirow[t]{2}{*}{$\begin{array}{c}t \\
\text { Hitung }\end{array}$} \\
\hline & $\begin{array}{c}0.430 \\
6\end{array}$ & $\begin{array}{c}0.246 \\
2\end{array}$ & $\begin{array}{c}0.079 \\
4\end{array}$ & $\begin{array}{c}0.085 \\
3\end{array}$ & & & \\
\hline $\mathrm{X} 2, \mathrm{Y} 1$, & 0.354 & 0.246 & 0.080 & 0.085 & 0.087 & & \\
\hline Y2 & 7 & 2 & 9 & 3 & 3 & 0.0356 & 2.4558 \\
\hline
\end{tabular}

\section{Pembahasan}

Pengaruh nilai yang diterima pelanggan terhadap kepuasan pelanggan diuji melalui hipotesis $\mathbf{H}_{\mathbf{1}}$. Hasil pengujian menunjukkan bahwa nilai yang diterima pelanggan secara langsung memiliki pengaruh terhadap kepuasan pelanggan. Hal ini berarti meningkatnya nilai yang diterima pelanggan menggunakan layanan pembelian tiket kereta api secara online di Stasiun Kota Baru Malang dapat meningkatkan kepuasan pelanggan. Temuan ini konsisten dengan penelitian Kuo, et al. (2009) menunjukkan bahwa nilai yang diterima oleh pelanggan memberikan pengaruh signifikan terhadap kepuasan pelanggan. Auka (2012) dalam penelitiannya menunjukkan derajat kepuasan pelanggan ditentukan oleh biaya yang dibayarkan oleh pelanggan terhadap apa yang diterima, hal ini berkontribusi terhadap nilai yang diterima pelanggan. Apabila nilai yang diterima pelanggan naik maka kepuasan yang diterima pelanggan naik juga. Lee (2010) dalam penelitiannya juga menunjukkan bahwa para pelaku bisnis harus meningkatkan nilai yang diterima oleh pelanggan untuk meningkatnya kepuasan pelanggan. Semakin tinggi nilai yang dirasakan oleh pelanggan maka semakin besar juga pelanggan akan menjadi puas (Chen dan Tsai, 2008).

Pengaruh nilai yang diterima pelanggan terhadap loyalitas pelanggan diuji melalui Hipotesis $\mathbf{H}_{2}$. Hasil pengujian menunjukkan bahwa nilai yang diterima pelanggan secara langsung memiliki pengaruh terhadap loyalitas pelanggan. Hal ini berarti meningkatnya nilai yang diterima pelanggan menggunakan layanan pembelian tiket kereta api secara online di Stasiun Kota Baru Malang dapat meningkatkan loyalitas pelanggan. Nilai yang diterima pelanggan merupakan imbalan yang diterima oleh pelanggan atas kualitas dan pengorbanan yang membuat pelanggan tetap menggunakan jasa layanan yang ditawarkan (Lee, 2010). Penelitian yang dilakukan oleh Ishaq (2012); Auka (2012); dan Chen dan Tsai (2008). Menunjukkan nilai yang diterima pelanggan berpengaruh secara signifikan terhadap loyalitas pelanggan

Pengaruh Kualitas Pelayanan terhadap Kepuasan Pelanggan diuji melalui Hipotesis $\mathbf{H}_{\mathbf{3}}$. Hasil pengujian menunjukkan bahwa kualitas pelayanan memiliki pengaruh yang positif dan signifikan terhadap kepuasan pelanggan. Hal ini berarti meningkatnya kualitas pelayanan menggunakan layanan pembelian tiket kereta 
api secara online di Stasiun Kota Baru Malang dapat meningkatkan kepuasan pelanggan. Temuan ini konsisten dengan penelitian Kuo, et al. (2009) dan Lee (2010) menunjukkan kualitas pelayanan memberikan pengaruh langsung signifikan terhadap kepuasan pelanggan.

Pengaruh kualitas pelayanan terhadap loyalitas pelanggan diuji melalui Hipotesis $\mathbf{H}_{4}$. Hasil pengujian menunjukkan bahwa kualitas pelayanan secara langsung tidak memiliki pengaruh signifikan terhadap loyalitas pelanggan. Hal ini berarti meningkatnya kualitas pelayanan menggunakan layanan pembelian tiket kereta api secara online di Stasiun Kota Baru Malang diindikasikan berpengaruh sangat rendah pada loyalitas pelanggan. Penyebab hasil penelitian pengaruh kualitas pelayanan terhadap loyalitas pelanggan tidak signifikan karena pelanggan tidak bisa loyal kepada perusahan, apabila pelanggan tersebut belum merasakan kepuasan terlebih dahulu. Temuan ini diperkuat oleh penelitian Cristobal, et al. (2007) bahwa kualitas pelayanan tidak berpengaruh secara signifikan terhadap terhadap loyalitas pelanggan dalam kelompok pembeli, hal ini karena masih adanya kekhawatiran para pembeli bila akan keamanan data yang diberikan akan disalahgunakan oleh penyedia jasa sehingga menyebabkan kualitas pelayanan secara langsung tidak memiliki pengaruh signifikan terhadap loyalitas pelanggan.

Pengaruh kepuasan pelanggan terhadap loyalitas pelanggan diuji melalui Hipotesis $\mathbf{H}_{5}$. Hasil pengujian menunjukkan bahwa kepuasan pelanggan secara langsung memiliki pengaruhyang positif dan signifikan terhadap loyalitas pelanggan. Elkhani, et al. (2014) dalam penelitiannya menunjukkan kepuasan pelanggan berpengaruh secara langsung dan signifikan terhadap loyalitas pelanggan. Dalam penelitiannya didefinisikan bahwa loyalitas pelanggan secara eksplisit sebagai keputusan untuk membeli layanan kembali dan merekomendasikan layanan terhadap orang lain. Dalam penelitiannya Auka (2012) dan Cristobal, et al. (2007) juga menguatkan hubungan yang signifikan antara kepuasan pelanggan dan loyalitas pelanggan.

Pengaruh nilai yang diterima pelanggan terhadap loyalitas pelanggan melalui kepuasan pelanggan diuji melalui $\mathbf{H}_{6}$. Hasil pengujian menunjukkan bahwa terdapat pengaruh tidak langsung antara kualitas pelayanan terhadap loyalitas pelanggan melalui kepuasan pelanggan dalam menggunakan layanan pembelian tiket kereta api secara online di Stasiun Kota Baru Malang. Dari penelitian juga menunjukkan terdapat pengaruh langsung yang signifikan antara kepuasan pelanggan terhadap loyalitas pelanggan. Dengan demikian kepuasan pelanggan adalah sebagai mediasi kualitas pelayanan terhadap loyalitas. Hal ini sesuai dengan penelitian dari Lee (2010) menunjukkan nilai yang diterima pelanggan dimediasi penuh oleh kepuasan konsumen untuk berpengaruh terhadap loyalitas. Hasil tersebut dikuatkan juga oleh penelitian yang dilakukan oleh Auka (2012) yang menyatakan nilai yang diterima pelanggan dimediasi penuh oleh kepuasan konsumen untuk berpengaruh terhadap loyalitas.

Pengaruh kualitas pelayanan terhadap loyalitas pelanggan melalui kepuasan pelanggan diuji melalui $\mathbf{H}_{7}$. Hasil pengujian menunjukkan bahwa terdapat pengaruh tidak langsung antara kualitas pelayanan terhadap loyalitas pelanggan melalui kepuasan pelanggan dalam menggunakan layanan pembelian tiket kereta api secara online di Stasiun Kota Baru Malang. Hasil penelitian juga menujukkan terdapat pengaruh yang signifikan antara kepuasan pelanggan terhadap loyalitas pelanggan. Dengan demikian kepuasan pelanggan berperan sebagai mediasi kualitas pelayanan terhadap loyalitas. Hal ini sesuai dengan penelitian dari Lee (2010) menunjukkan kualitas pelayanan dimediasi penuh oleh kepuasan konsumen untuk berpengaruh terhadap loyalitas. Hasil tersebut dikuatkan juga oleh penelitian yang dilakukan oleh Auka (2012) yang menyatakan kualitas pelayanan dimediasi penuh oleh kepuasan konsumen untuk berpengaruh terhadap loyalitas.

Dari hasil pengujian hipotesis terbukti bahwa gender (jenis kelamin) bukan sebagai moderasi pengaruh nilai yang diterima pelanggan terhadap loyalitas pelanggan. Hal ini menunjukkan bahwa baik perempuan maupun laki-laki tidak berbeda dalam memberikan pengaruh pada hubungan nilai yang diterima pelanggan terhadap loyalitas pelanggan terhadap layanan pembelian tiket kereta api secara online di Stasiun Kota Baru Malang. Dalam penelitian Hamidizadeh, et al (2011) menjukkan bahwa gender tidak memoderatori hubungan antara nilai yang diterima pelanggan dan loyalitas pelanggan. Hal ini dikuatkan oleh penelitian Stan (2015) yang menunjukkan gender tidak memoderasi hubungan antara nilai yang diterima pelanggan dan loyalitas pelanggan. 
Dari hasil pengujian hipotesis terbukti bahwa gender (jenis kelamin) bukan sebagai moderasi pengaruh kualitas pelayanan terhadap loyalitas pelanggan. Hal ini menunjukkan bahwa baik perempuan maupun laki-laki tidak berbeda dalam memberikan pengaruh pada hubungan kualitas pelayanan terhadap loyalitas pelanggan terhadap layanan pembelian tiket kereta api secara online di Stasiun Kota Baru Malang. Hal ini didukung oleh penelitian Hamidizadeh, et al (2011) menjukkan bahwa gender tidak memoderatori hubungan antara kualitas pelayanan dan loyalitas.

Dari hasil pengujian hipotesis terbukti bahwa gender (jenis kelamin) bukan sebagai moderasi pengaruh kepuasan pelanggan terhadap loyalitas pelanggan. Hal ini menunjukkan bahwa baik perempuan maupun laki-laki tidak berbeda dalam memberikan pengaruh pada hubungan kepuasan pelanggan terhadap loyalitas pelanggan terhadap layanan pembelian tiket kereta api secara online di Stasiun Kota Baru Malang. Penelitian Hamidizadeh, et al (2011) yang menunjukkan menunjukkan gender tidak memoderasi hubungan antara kepuasan pelanggan dan loyalitas pelanggan. Diperkuat oleh penelitian Stan (2015); dan Frank, et al (2013) yang menujukkan gender juga tidak memoderasi hubungan antara kepuasan pelanggan dan loyalitas pelanggan.

\section{Kesimpulan}

Nilai yang diterima pelanggan berpengaruh positif dan signifikan terhadap kepuasan pelanggan. Hal ini dapat dikatakan bahwa konsumen akan meningkatkan kepuasan pada PT KAI dalam hal pembelian tiket kereta api secara online di Stasiun Kota Baru Malang apabila PT KAI Malang meningkatkan nilai yg diterima pelanggan. Nilai yang diterima pelanggan berpengaruh positif dan signifikan terhadap loyalitas pelanggan. Hal ini dapat dikatakan bahwa konsumen akan meningkatkan loyalitas pada PT KAI dalam hal pembelian tiket kereta api secara online di Stasiun Kota Baru Malang apabila PT KAI Malang meningkatkan nilai yg diterima pelanggan.

Kualitas pelayanan berpengaruh positif dan signifikan terhadap kepuasan pelanggan. Hal ini dapat dikatakan bahwa konsumen akan meningkatkan kepuasan layanan pada PT KAI dalam hal pembelian tiket kereta api secara online di Stasiun Kota Baru Malang apabila PT KAI Malang menyediakan kualitas yang bagus.
Kualitas pelayanan berpengaruh positif dan tidak signifikan terhadap loyalitas pelanggan. Hal ini dapat dikatakan bahwa konsumen akan tidak selalu secara signifikan meningkatkan loyalitas pada PT KAI dalam hal pembelian tiket kereta api secara online di Stasiun Kota Baru Malang apabila PT KAI Malang menyediakan kualitas yang bagus.

Kepuasan pelanggan berpengaruh positif dan signifikan terhadap loyalitas pelanggan. Hal ini disebabkan oleh pelanggan tiket kereta api secara online di Stasiun Kota Baru Malang menganggap bahwa tingkat loyalitas mereka terhadap PT KAI hasil dari rasa puas yang mereka peroleh dari layanan yang diberikan oleh pihak butik PT KAI. Kepuasan pelanggan memediasi antara variabel nilai yang dirasakan terhadap loyalitas pelanggan secara signifikan. Hasil ini dapat dijelaskan bahwa pelanggan akan merasa loyal jika pelanggan tersebut puas terhadap nilai yang diterima yang diberikan oleh layanan tiket kereta api secara online di Stasiun Kota Baru Malang. Kepuasan pelanggan memediasi antara kualitas pelayanan terhadap loyalitas pelanggan secara signifikan. Hasil ini dapat dijelaskan bahwa pelanggan akan merasa loyal jika pelanggan tersebut puas terhadap kualitas layanan yang diberikan oleh PT KAI Malang.

Gender (jenis kelamin) bukan sebagai moderasi nilai yang diterima pelanggan, kualitas pelayanan, dan kepuasan pelanggan terhadap loyalitas pelanggan. Hal ini menunjukkan bahwa baik perempuan maupun laki-laki tidak berbeda dalam memberikan pengaruh pada hubungan antar variable nilai yang diterima pelanggan, kualitas pelayanan, dan kepuasan pelanggan terhadap loyalitas pelanggan.

\section{Daftar Pustaka}

Anonymous. 2015. Internet Usage in Asia. http://www.internetworldstats.com/stats

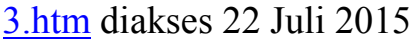

Anonymous. 2015. Transaksi Online Indonesia Capai Rp34,3 triliun. http://www.antaranews.com/berita/505 724/transaksi-online-indonesia-capairp343-triliun diakses 22 Juli 2015

Auka, D.O. 2012. Service quality, satisfaction, perceived value and loyalty among customers in commercial banking in Nakuru Municipality, Kenya. African Journal of Marketing Management. Vol. 4, No.5, pp. 185-203. 
Lee, Heeseok., Choi, Sue Young., and Kang, Young Sik. 2009. Formation of esatisfaction and repurchase intention: Moderating roles of computer selfefficacy and computer anxiety. Expert Systems with Applications. Vol. 36, pp. 7848-7859.

Lee, Hyung Seok. 2010. Factors Influencing Customer Loyalty of Mobile Phone Service: Empirical Evidence from Koreans. Journal of Internet Banking and Commerce. Vol. 15, No. 2, pp. 1-14.

Hidayat, Ali. 2014. KAI: Tak Ada Perbedaan Beli Online dan di Stasiun. http://metro.tempo.co/read/news/2014/ 04/27/083573536/kai-tak-adaperbedaan-beli-online-dan-di-stasiun. Diakses 20 Oktober 2015

Kotler, Philip and Keller, Kevin Lane. 2013. Marketing Management. $14^{\text {th }}$ Edition. Pearson Education. Inggris.

Kotler, Philip dan Keller, Kevin Lane, 2009, Manajemen Pemasaran Jilid 1, Penerbit Erlangga, Jakarta

Purwanto, D., \& Hidayat, W. S. 2011. Belanja Online Indonesia Rp 2 Triliun,Peluang Masih Besar. http://tekno.kompas.com/read/2011/12/ 13/18014276/Belanja.Online.Indonesia. Rp.2.Triliun..Peluang.Masih.Besar diakses 10 Juli 2015

Rochmanuddin. 2013. PT KAI Target Jual Tiket Online Lebih $80 \%$. http://news.liputan6.com/read/660569/p t-kai-target-jual-tiket-online-lebih-80 diakses 20 Juli 2015

Tierney, L. 2009. A Gender-Based Genetic Algorithm for the Automatic Configuration of Algorithms. Principles and Practice of Constraint Programming - CP 2009 pp 142-157.

Tjiptono, Fandy. 2000. Prinsip dan Dinamika Pemasaran. Edisi Pertama. J \& J Learning. Yogyakarta.

Zeithaml, V.A. 2000. Service quality, profitability, and the economic worth of customers: what we know and what we need to learn. Academy of Marketing Science Journal. Vol. 28, No. 1, pp. 6785. 